\title{
Daylength and development in four species of Ceramiaceae (Rhodophyta)
}

\author{
D. GarbarY* \\ Department of Botany, Liverpool University; \\ P.O. Box 147 Liverpool, L69 3BX, U.K.
}

\begin{abstract}
Developmental parterns in four species of Ceramiaceae were determined using excised thallus apices grown under a range of light periods. Models of thallus development and organization based on these patterns are presented. Increased rates of apical cell division, greater growth of apical fragments and increased average cell size were found with increasing number of hours light per day between $8-16$ and 16-8 h. No aspect of growth investigated was associated with photoperiodic phenomena, and growth occuring during the light break $(8-7.5-1-7.5 \mathrm{~h})$ was intermediate between that in 8-16 and 12-12 h. Three patterns of cell elongation were found in the four species in which (1) cell age, (2) cell age and position and (3) cell age, cell position and light period determined cell length at different axial cell positions. Elongation was followed within cells, along axes of Antithamnion spirographidis for plants grown under different day lengths. Three regions of development were found along main axes: (1) an apical region in which basipetal expansion was greater than acropetal expansion. (2) a zone of stability with equal elongation in apical and basal growth region of cells, and (3) a basal region with greater acropetal expansion. With increasing daylength, the zone of stability was extended to greater ranges of cell length.
\end{abstract}

\section{INTRODUCTION}

Patterns of thallus development in the Florideophyceae have been outlined by Dixon $(1958,1963,1966,1971,1973)$ who considered that thallus form can be expressed as the result of three processes which refer to the disposition, shape and longevity of axes. In more general terms, morphology depends upon the interaction of cell division, cell enlargement and cell differentiation. The relationship between these processes and various environmental factors remains poorly understood and was considered by Dixon (1970) to be one of the major problems in the study of phenotypic variation and the taxonomy of marine algae. One approach to the investigation of phenotypic variation taken up in this report is the study of morphogenesis under controlled conditions. In this way, patterns of development can be defined and modifications induced by environment on the basic morphogenetic processes determined.

* Present address: Department of Botany, University of British Columbia, Vancouver, B.C., V6T 1W5, Canada. 
The approach outlined above has been used successfully in studies on the effects of environment on developmental patterns in Griffitbsia pacifica Kylin (Waaland \& Cleland, 1972), Pleonosporium squarrulosum (Harv.) Abbott (Murray \& Dixon, 1973, 1975) and Ceramium rubrum (Huds.) C. Ag. (Garbary et al., 1978). Although the above work has shown that daylength can modify patterns of development to greater or lesser extents, such modifications can be largely explained as purely photosynthetic phenomena. It remains to be demonstrated whether or not any of these responses are truly photoperiodic. In this study, responses to light period are reexamined in three species of Ceramium and in Antithamnion spirographidis Schiffner by means of critical photoperiodic experiments.

A second limitation of previous work (in particular that of Murray \& Dixon, 1975) is that cell length was only compared for cells in equivalent positions (equal number of segments from the apex) on plants grown under different conditions. Thus the importance of such factors as cell age or the amount of light received by a cell was not discussed. In this paper the role of these factors in cell elongation patterns is examined.

Patterns of elongation within cells can also be followed in uniaxial species in which the position of lateral branches allows a reference point for the examination of acropetal and basipetal expansion. Studies of this kind were initially suggested by Dixon (1971) and facilitated by the fact that members of the Ceramiaceae (at least five species in three genera) have one or two bands either at the distal or proximal end, or both, in which new cell wall material is deposited (Waaland et al., 1972; Waaland \& Waaland, 1975). No examination of possible modifications of intracellular elongation by different culture conditions (e.g. light intensity or period) was made, however. This was demonstrated by Murray \& Dixon (1975) who showed differential rates of expansion basipetally and acropetally, that could be modified by short and long days. In this report, patterns of intracellular elongation are considered for Antithamnion spirographidis with respect to the size and position of cells, and the effects of light period on these processes are examined.

\section{MATERIALS AND METHODS}

Four species of Ceramiaceae were used as experimental material. The time and place of collection of isolates were as follows: (1) Antithamnion spirographidis Schiffner; Dorset, Aug. 1977; (2) Ceramium echionotum J. Ag.; Anglesey, Sept. 1976; (3) C. rubrum (Huds.) C. Ag.; Anglesey, Jan. 1976; and (4) C. shuttleworthianum (Kütz.) Rabenh.; Isle of Man, July 1976. Plants were initially cultured in the medium of von Stosch (1964), however, experiments were carried out in Provasoli's ES (1968) medium at $15^{\circ}$ at a light intensity of 500-700 lux provided by Osram, daylight fluorescent tubes at light periods of $8-16,12-12,16-8$ and $8-7.5-1-7.5 \mathrm{~h}$.

Experiments were carried out using excised thallus apices from several large plants. Five or seven plant segments (1-5 mm in length) were placed in each of two replicate plastic petri-dishes $(60 \mathrm{~mm}$ in diameter). The fragment lengths and number 
of axial cells in the principal axis of all plants were recorded at the beginning of experiments and monitored at weekly intervals (when medium was replenished) for periods of two to four weeks. Fragments of $A$. spirographidis were harvested after only two weeks, as a longer growth period in the longer daylengths would have resulted in entangled plants that were too large separate. Early harvesting also ensured that crowding would not affect the rate of growth. Cultures of C. rubrum were left for a fourth week due to a lag period before growth stabilized. In the remaining species fragments were grown for three weeks. When an experiment was completed plants were harvested and the cell length of thirty consecutive cells, commencing subapically, was measured for three regenerates from each petri-dish. Apical regions were ignored as the density of small cells often prevented measurement. Thus in $A$. spirograpbidis, the first cell to be measured was $15-19 \mu \mathrm{m}$ in length and in Ceramium spp. 27-33 $\mu \mathrm{m}$. In the figures and text this cell is referred to as axial, or segment cell number one.

Rates of cell division, in terms of number of cell divisions per day, were calculated by subtracting the average number of cells present in the main axis of fragments under each condition at the start of the experiment, from the average present at the end of the growth period, and dividing by the number of days growth. For. C. rubrum increments during the first week were not considered.

Further analyses were also made using $A$. spirographidis: in addition to the total cell length, the length of the cell distal to the oppositely placed pericentral cells was measured for the $10 \mathrm{th}, 15 \mathrm{th}, 20 \mathrm{th}$. . . 50th cell in each of the axes measured above.

\section{RESULTS AND DISCUSSION}

\section{Apical cell division}

Differences in rates of apical cell division attributable to daylength were apparent in the four species, and the four light periods showed at least three increases (Figs 1-4) in the number of segment cells of regenerating fragments. The general pattern was an increase in the number of apical cell divisions with number of hours light per day. These differences in increments, however, were not always evident after one or even two weeks growth as the presence of lag phases and the occurrence of low division rates often masked the differential effects of daylength until the later stages of development. C. rubrum had the longest lag period, of almost a week, and little apical cell division occurred irrespective of daylength. This is attributed to a longer period of recovery from excision before apical cell division recommenced, as compared with the other species. A slower rate of regeneration was also evident in rhizoid development, which occurred in $A$. spirographidis after 1-2 days, but required 3-4 days in C. rubrum. After one week, however, there was often a difference in the number of segment cells betweens short (8-16) or long (16-8 h) days and the remaining conditions. The total increase in number of segment cells in the light break (8-7,5-1-7.5 h) was always greater than in eight hours light and 
except for C. echionotum was always less than values in $12 \mathrm{~h}$ light (in this species differences between 12-12 $\mathrm{h}$ and the light break were not significant).

Values for the rates of apical cell division in terms of number of cell divisions per day (calculated from Figs 1-4) are shown in Table 1. In all species, the rate of division in $8 \mathrm{~h}$ light was almost half that in $16 \mathrm{~h}$ and the values for $12 \mathrm{~h}$ were intermediate between those for short and long days. Cell division rates in this study

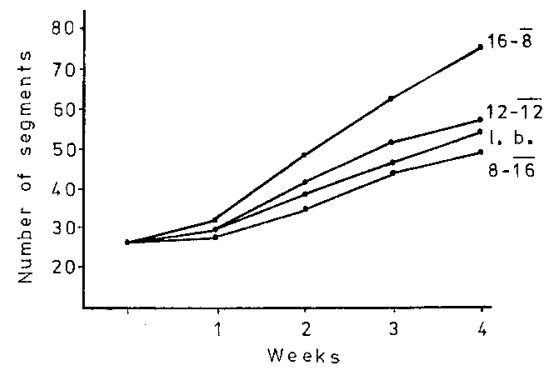

Fig. 1: Ceramium rubrum (standard errors 0.6-2.4). The effects of light period on rates of apical cell division. (Note: in all figures $1 . \mathrm{b}$. refers to light break, 8-7.5-1-7.5 h)

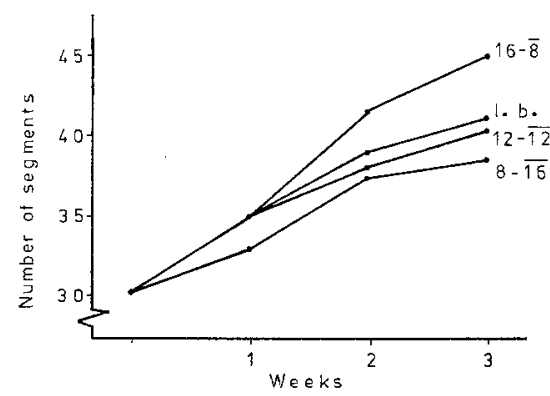

Fig. 3: Ceramium echionotum (s. e. 0.5-1.2). The effects of light period on rates of apical cell division

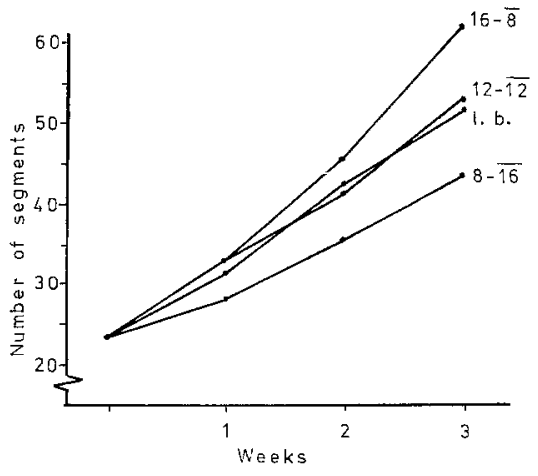

Fig. 2: Ceramium shuttlewortbianum (s. e. 1.1-4.0). The effects of light period on rates of apical cell division

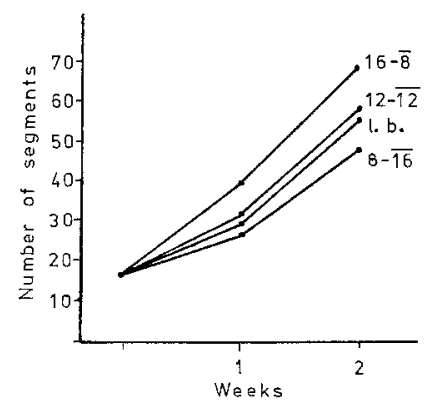

Fig. 4: Antithamnion spirographidis (s. e. 1.3 to 2.3). The effects of light period on rates of apical cell division

are similar to those reported in the literature for other species of Ceramiaceae which generally vary from one to two divisions per day (Dixon \& Richardson, 1970; Duffield et al., 1972; Waaland \& Cleland, 1972; Murray \& Dixon, 1973) although a higher rate of 2.8 cells per day was reported by Konrad-Hawkins (1964) for Callithamnion roseum at 14-10 h. This range is now extended in both directions with lower rates of 0.3 cells per day in $C$. echionotum in short days and a higher rate of 3.5 for A. spirographidis in long days.

Chapman \& Burrows (1970) used a function referred to as Mean Daily Illuminiance [M.D.I. = illumination $(\mathrm{lux}) \times$ length of light period $(\mathrm{h}) / 24 \mathrm{~h}$ ] as a means 
of relating the total amount of light received to growth of Desmarestia aculeata. This function probably also applies to many members of the Ceramiaceae, or at least corresponds to the approximately linear relationship between light period and rates of division over the range 8 to $16 \mathrm{~h}$ light per day. In previous studies, this could not be determined as linear, as usually no more than two daylengths were used.

Between 16-8 $\mathrm{h}$ and continuous light, however, the correlation between M. D. I. and rates of cell division does not hold. Waaland et al. (1972) demonstrated an increase in the rate of cell division of 0.4 cells per day from 8 to $16 \mathrm{~h}$ light with virtually no increase from 16 to $24 \mathrm{~h}$ light. Dixon \& Richardson (1970) have shown that there may even be a decrease in growth rates when comparing daylengths of $16 \mathrm{~h}$ and continuous light. In a previous study of C. rubrum from eastern Canada, Garbary (1975) found no increase in the number of axial cells formed from 16-8 $\mathrm{h}$ to continuous light. As demonstrated by Murray \& Dixon (1973) great care must be taken in applying figures for light intensity to M. D. I. and cell division, as minimum responses and saturation effects make useful ranges difficult to determine. There may also be differential responses among species so that M. D. I. and cell division are linear over different ranges of light intensity. Despite these limitations, the correspondance of M. D. I. to rates of cell division between daylengths of 8 to $16 \mathrm{~h}$ suggests a lack of a photoperiodic trigger and that control of cell division is by photosynthetic limitation.

\section{Fragment length}

Increase in the length of regenerating fragments includes increments due to both cell enlargement and cell division, of which cell enlargement is the more important. The maximum and minimum increments for cell division were $300 \%$ (A. spirographidis, 16-8 h, 2 weeks) and $25 \%$ (C. echionotum, $8-16 \mathrm{~h}, 3$ weeks). The corresponding values for increase in fragment length were $1100 \%$ and $45 \%$ respectively for the same species under similar conditions (Figs 5-8). Although the latter figure also includes the increments from apical cell division, the major proportion of this growth is due to cell enlargement alone. This has been previously demonstrated for C. rubrum and C. diaphanum (Garbary 1975; Garbary et al., 1978). That overall growth of regenerates is primarily a function of cell enlargement is not surprising, since cell division occurs only at the apex while cell enlargement proceeds in all cells in an axis.

Because the increase in fragment length was greater in magnitude than the change in number of segment cells, the former character may be more useful in monitoring growth in different light periods (it is also a less laborious procedure). Indeed, increases in fragment length after only one week could be directly related to daylength in three of the four conditions (Figs 5-8) and at the end of the growth period, fragment lengths of $C$. echionotum and C. shuttleworthianum corresponded with number of hours light received per $24 \mathrm{~h}$. In the remaining species, there was little or no difference between the light break and 12-12 h. Thus the effect of the light break on overall fragment growth remains equivocal. In C. echionotum and 
C. sbuttlewartbianum the added hour of light during the dark period functioned as a photosynthetic effector, whereas with C. rubrum and A. spirographidis the response was more complicated as the light break initiated more growth than can be explained from its duration. Differences between these pairs of species, however, might be due to insufficient replication.

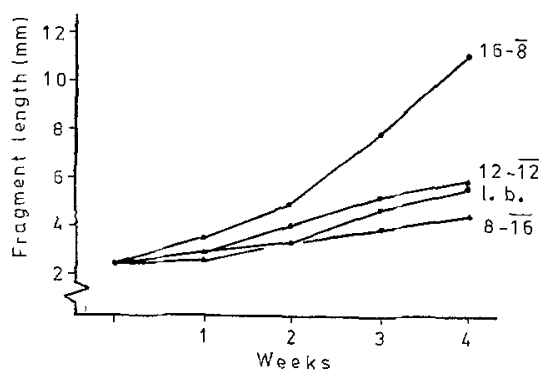

Fig. 5: Ceramium rubrum (s, e. 0.1-0.3). The effects of light period on rates of fragment growth

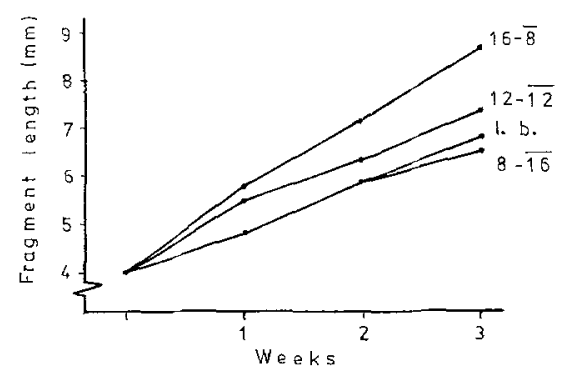

Fig. 7: Ceramium ecbionotum (s. e. 0.1-0.3). The effects of light period on rates of fragment growth

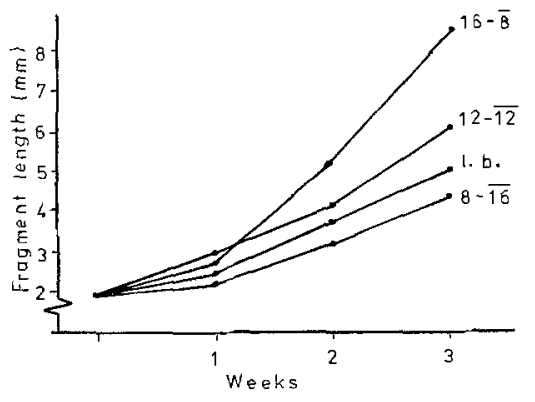

Fig. 6: Ceramium shuteleworthianum (s. e. 0.2 to 0.6). The effects of light period on rates of fragment growth

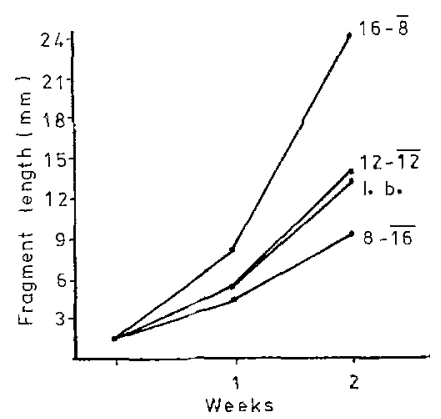

Fig. 8: Antitbamnion spirographidis (s. e. $0.3-1.2$ ). The effects of light period on rates of fragment growth

Although there did not appear to be any photoperiodic effects on growth and morphology in this study, unlike other species C. rubrum produced plants of different morphologies in long and short days. Under long days plants were similar to those produced by isolates of the same species from Canada (Garbary et al., 1978) with definite uncorticated regions between the nodes. Under short days and in the light break plants were morphologically similar and showed typical C. rubrum cortication (i.e. completely corticated). Thus the mechanism controlling the development of cortical bands in C. rubrum in different daylengths is probably not a photoperiodic response as was suggested previously (Garbary et al., 1978). 


\section{Average cell length}

Average axial cell length of regenerating thallus apices was considerably modified by growth in different light periods (Figs 9-12). In all species there was a decrease in the number of axial cells per millimeter and the extent of the decrease corresponded to the increase in number of hours light per day. As with the parameters of growth discussed above, the light break did not function as a photoperiodic trigger and effects can be attributed to the extra hour of light serving to increase photosynthesis. As reported by Garbary et al. (1978) for C. rubrum, however, long days (16-8 h) produced morphogenetic changes in cell length and development of cortical bands. This effect was evident in C. rubrum (Fig. 9) where the decrease in number of axial cells per mm under 16-8 $\mathrm{h}$ was more than double that in plants incubated at 12-12 h. After four weeks no change was apparent under short days. In the remaining species (and all other regenerates of C. rubrum) the number of axial cells per $\mathrm{mm}$ decreased with time and the different daylengths controlled only the rates at which this proceeded. In addition, evidence from studies of cell lengths in given positions on plants (see below), suggests that the maximum cell length may be controlled by light period.

In all species, there was an increase in the average cell length in an axis (Figs 9-12). This was due to the relative stability in the size of the apical region and the steadily decreasing proportion of the growing axis length taken up by the apex. The apical region in Ceramium can be defined as that part of the axis in which axial cell diameter is greater than cell length. The length of the apical region is influenced by the light in as much as plants grown under long days have smaller apical regions (Garbary, 1975; Garbary et al., 1978). With regards to the decreasing proportion of the plant length taken up by the apex, regeneration of an apical fragment is similar to the development of a sporeling. A critical difference between these systems, however, is that average cell length is greater in apical fragments. After excision the apex does not continue growing as previously: the apical filament that does develop consists of smaller axial cells similar to that of a sporeling. Thus there may be little or no change in average size of axial cells during the first, or even second week (as in C. rubrum, Fig. 9) and average axial cell size can even decrease (Fig. 9; C. shuttleworthianum, Fig. 10). This phenomenon was usually more pronounced under short days. After the apex has regenerated growth can proceed as in a normal plant with a gradual increase in average cell length. As a larger proportion of cells reach their maximum length, the rate of increase of maximum cell length slows. This was demonstrated for A. spirographidis (Fig. 12) where by the end of the second week the rate of increase had declined considerably. The Ceramium spp. had not reached this stage by the third or fourth week.

The development of fragments thus proceeds through a number of stages. The first of these is a lag phase during which no growth occurs and the fragments recover from excision. During the second stage, rhizoid production occurs and the apices resume division, with the initial development of the apical region similar to that of a sporeling of corresponding size to the fragment. By this stage little or no increase in average cell length has occured. Increase in average cell length occurs 
only after the apical region has fully redeveloped to that corresponding to a plant of equivalent size and the conditions under which it is grown. Until this stage the apical fragment is regenerating, whereas after this, the fragment can be considered as a maturing plant (i.e. as a developing sporeling). A third stage is characterized by rapid increases in plant length and an increase in axial cell size. In this study,

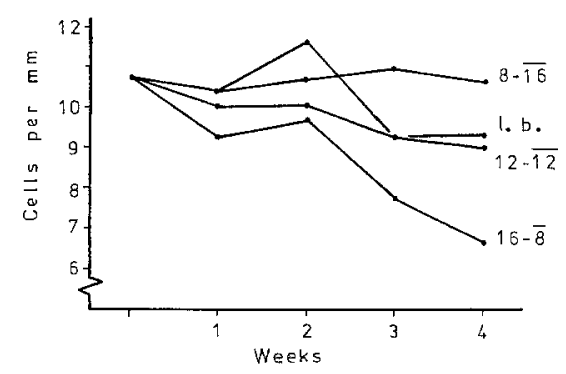

Fig. 9: Ceramium rubrum (s. e. 0.1-0.3). The effects of light period on rates of cell enlargement

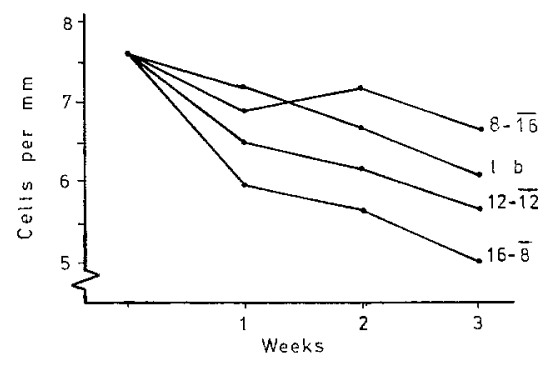

Fig. 11: Ceramium echionotum (s. e. 0.1-0.3). The effects of light period on rates of cell enlargement

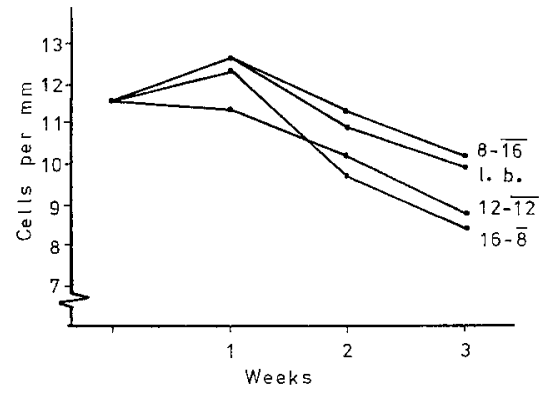

Fig. 10: Ceramium shuttlewortbianum (s. e. $0.2-1.4)$. The effects of light period on rates of cell enlargement

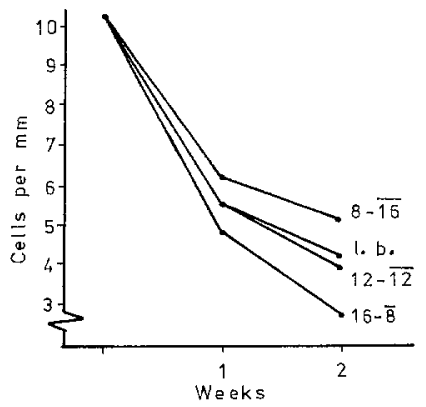

Fig. 12: Antithamnion spirographidis (s. e. $0.1-0.3$ ). The effects of light period on rates of cell enlargement

all species had developed to this stage during the two to four week incubation period (at least in some conditions). Developmental changes of regenerates were not followed beyond this stage, although the decrease in the rate of axial cell growth in A. spirographidis during the second week (Fig. 12) indicates a further stage in maturation. If this trend continues, then average cell length would be expected to stabilize as greater numbers of cells reach their maximum dimension (as controlled by culture conditions), attain reproductive maturity and become senescent.

\section{Cell elongation}

Patterns of cell elongation in the main axes of C. rubrum, C. echionotum and C. shuttlewortbianum are shown in Figures 13-15 respectively. Each of these species 
has a distinctive pattern of elongation that can be modified to different extents by growth in a range of daylengths. The basic pattern of elongation may be referred to as daylength positive. In this developmental pattern cell length at a given position can be modified by daylength so that cells which have received a greater number of hours light per day are larger. Cell length is also dependent upon cell age so that

Table 1

Effects of light period on rates of apical cell division (number of divisions per day)

\begin{tabular}{lcccc|}
\hline & \multicolumn{4}{c}{ Daylength (h) } \\
Species & $8-\overline{16}$ & $8-\overline{7.5}-1-\overline{7.5}$ & $12-\overline{12}$ & $16-\overline{8}$ \\
\hline Antithamnion spirographidis & 2.1 & 2.9 & 2.7 & 3.6 \\
Ceramium echionotum & 0.4 & 0.5 & 0.5 & 0.7 \\
C. rubrum & 1.0 & 1.1 & 1.3 & 2.0 \\
C. shuttleworthianum & 1.0 & 1.3 & 1.4 & 1.8 \\
\hline
\end{tabular}

if in Fig. 13 lines are drawn connecting cell positions of similar ages (calculated from the division rates in Table 1), then differences in length between cells of equal ages grown under $8-16$ and $16-8 \mathrm{~h}$ are even more apparent than if only cell position is accounted for. Thus after ten days growth (from segment one), cells at 8-16 h were $55 \mu \mathrm{m}$ long and at $16-8 \mathrm{~h} 95 \mu \mathrm{m}$ long. Corresponding values for 15 days were 70

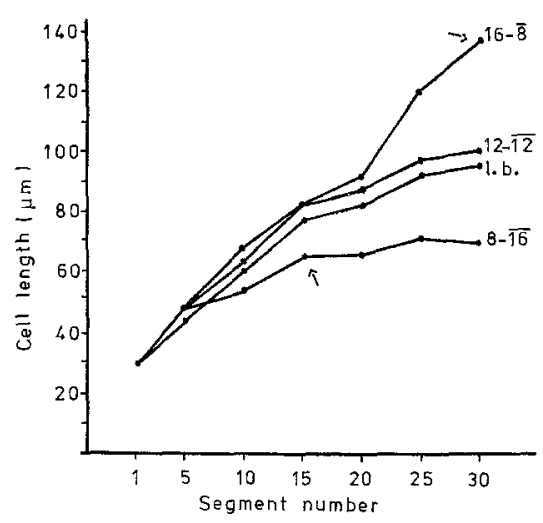

Fig. 13: Patterns of cell elongation in Ceramium rubrum in different daylengths. (Arrows indicate 15 days growth in 8-16 and 16-8 h) (s. e. $2.0-9.8$ )

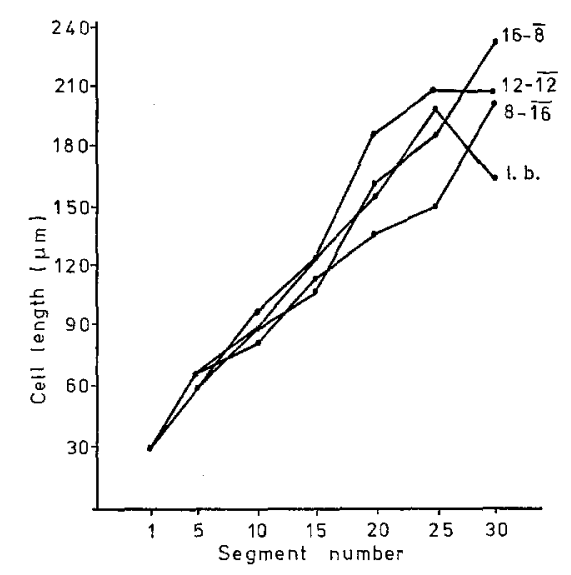

Fig. 14: Patterns of cell elongation in Ceramium echionotum in different daylengths

(s. e. $3.2-31.8$ )

and $135 \mu \mathrm{m}$ (see arrows Fig. 13). These values indicate that cell dimensions may be independent of cell position. Thus cells that have received similar total number of hours light are of similar size. Cell length in daylength positive plants therefore appears to be controlled by photosynthetic limitation. This pattern of elongation, as demonstrated in this study for C. rubrum and $A$. spirographidis (figure not 
shown), requires a modification of the suggestion of Dixon (1971) that position in a filament is a scale by which age and developmental comparisons can be made. Thus growth rates must be known before equivalent positions can be determined. The pattern of elongation in Plenosporium squarrulosum (Murray \& Dixon, 1975) also conforms to a daylength positive condition.

A second pattern of elongation was found in C. echionotum and may be referred to as daylength neutral. It is characterized by the fact that cells in equivalent positions (segment numbers) on plants grown under a range of daylengths have similar cell lengths (Fig. 14). Cell dimensions in this developmental system are dependent upon cell age and cell position. A similar pattern of elongation was also suggested by Waaland \& Cleland (1972) for Griffithsia pacifica, who concluded that light period had little effect on modifying the dimensions of cells in equivalent positions. Plants that exhibit this pattern of growth should also have similar maximum cell dimensions (regardless of light period), that is reached at similar distances and axial cell numbers from the apex.

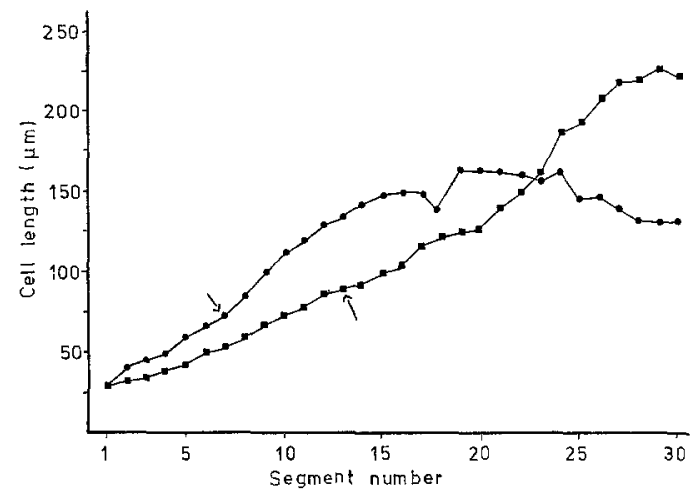

Fig. 15: Patterns of cell elongation in Ceramium shuttlewortbianum in different daylengths (arrows indicate 6 days growth) (standard errors between segments 5 and 20 were $0.8-11.0$ ). $-8-16 \mathrm{~h},-16-8 \mathrm{~h}$

A more complicated pattern of cell elongation was found in C. shuttleworthianum in which cells near the apex of the plant were larger in short days (8-16 h) than in long days (16-8 h) (Fig. 15). In addition, cells that received a similar number of hours light (calculated from the rates of division in Table 1), were larger under short days. Cell lengths roughly corresponded to cell age (see arrows Fig. 15), with cells grown under long days being approximately $20 \%$ larger. An explanation of this phenomenon is difficult, especially as after segment 25 (and ten days growth) elongation changed to daylength positive. Plants grown in the light break and at 12-12 $\mathrm{h}$ gave intermediate results to those found in long and short days. The pattern of elongation found in this species may be referred to as daylength negative. A slightly modified daylength negative growth pattern was also shown by Garbary (1975) for C. diaphanum. 


\section{Intracellular elongation in Antithamnion spirographidis}

In A. spirographidis, the lateral branches were formed near the apex before extensive cell elongation occurred. These laterals were formed at the immediate apex of each segment cell and in this region about $20 \%$ of the cell length was distal to the lateral pit connection. This differs from Plenosporium squarrulosum where the lateral branches are produced midway along the length of the parent axial cell (Murray \& Dixon, 1975). Further from the apex in A. spirograpbidis, evident cell expansion occurred at both the distal and proximal ends, and a distinct zone appeared between the lateral branches and the apex of the cell. Cell elongation was primarily basipetal and the percentage of the cell length distal to the lateral branches decreased to 11-13\%. Until this stage, differences among plants growing at different light periods were not evident (Fig. 16, segment 10). Between segments 10 and 25 the proportion of acropetal and basipetal growth in plants grown under short days (8-16 h) showed little change. The relative amount of basipetal growth then increased until segment 40 where the percentage of the cell distal to the laterals decreased to $7 \%$. After segment 40 the relative growth reversed (above and below the lateral branches) and

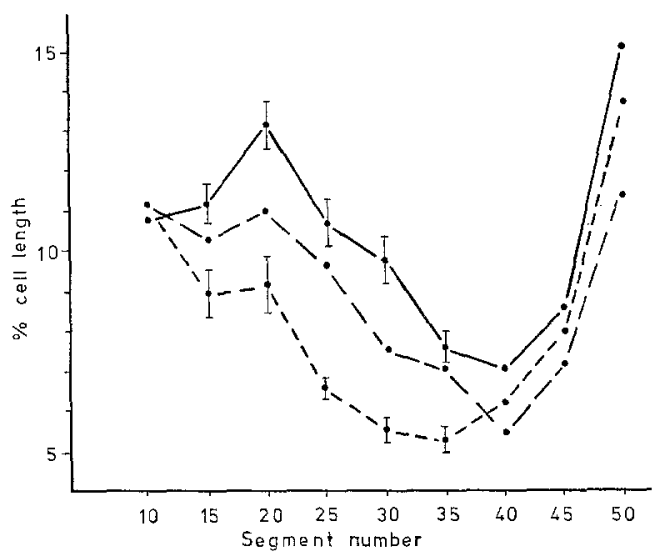

Fig. 16: The relationship between segment position and the per cent of the cell distal to the pit connections in Antithamnion spirographidis grown at different light periods (lines- 8-16 h), long dashes- $12-12 \mathrm{~h}$, short dashes- $16-8 \mathrm{~h}$ ) (limits indicate $\pm \mathrm{s.}$ e.)

a major increase in the apical proportion of the cell occurred. Similar patterns were also found in plants grown under 12-12 and 16-8 h except that percentage values decreased nearer to the apex under longer days. Thus for a larger proportion of the axis length, the relative acropetal expansion was greater under longer light periods. The relative acropetal expansion also reached lower values in long days (5.3 vs $7.1 \%$ in short days). Values for the light break (not shown in Fig. 16) were similar to those for 12-12 h. For segments 30 to 40 , however, results were intermediate between those for 8-16 and 12-12 h. These results are comparable to those of Murray \& 


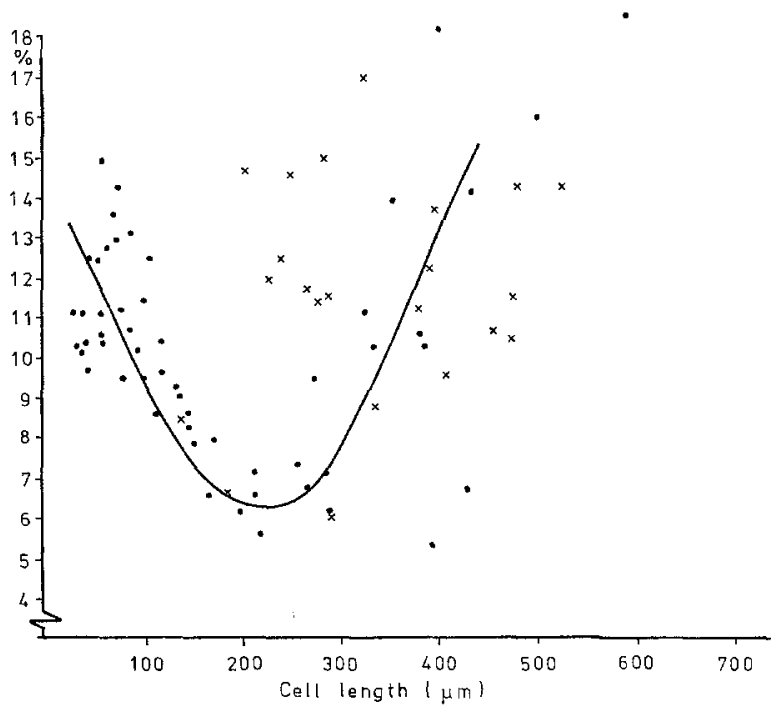

Fig. 17: The relationship between cell length and the per cent of the cell distal to the pit connections in Antithamnion spirograpbidis grown at 8-16 h. X's represent cells for which position is unknown

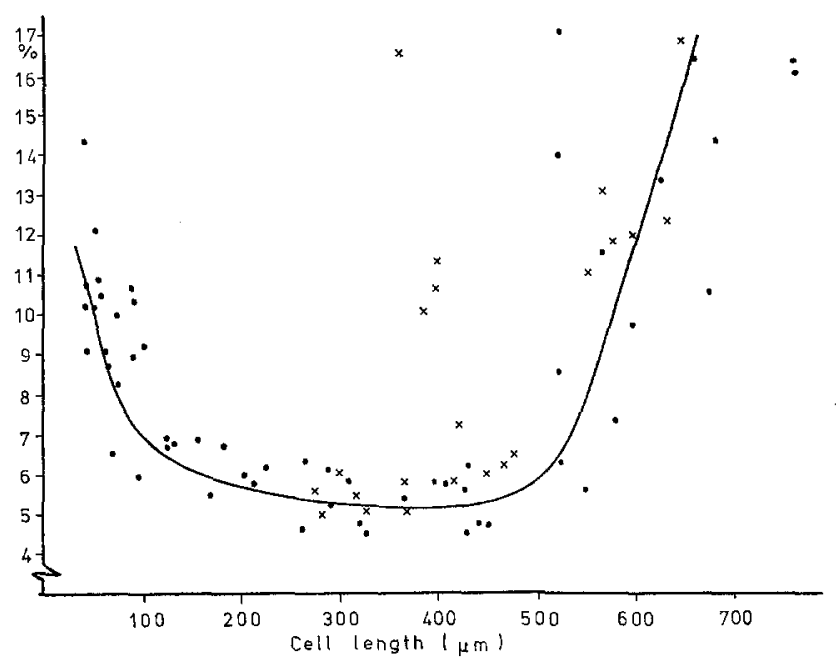

Fig. 18: As in Figure 17 except for plants at 16-8 h

Dixon (1975) in as much as long daylengths significantly increased the relative basipetal elongation. These authors, however, did not find changing patterns of intracellular elongation along axes.

The above results show the relationship between relative acropetal and basipetal cell expansion to cell position. This does not account for the fact that cell length 
also changes with cell position and that cell size can be related to light period. In addition, the slower growth rate of plants under short days (Figs 4 and 8) means that segment 50 is virtually at the base of plants, whereas under long days, this position is a considerable distance from the base. Thus segment position cannot be used as the sole index of vegetative maturity and cell length might give a better reflection of developmental state. In Figures 17-18, the relationship between acropetal and basipetal cell expansion and cell length is considered for plants grown under short (8-16) and long (16-8 h) days respectively. It should be pointed out that these figures are based primarily on cell measurements used above to relate intracellular cell expansion with cell position. A number of additional points are also included (see legends for figures) for which cell position was not recorded. Results shown in Figures 17-18 have several features in common which include (a) a similar basic shape to the curves and (b) a wide scatter of points for both the smaller and larger cells in each condition. There were a number of differences between cells of plants grown under the two light periods, however. In short days, relative acropetal and basipetal expansion were continually changing with cell length, so that when cells reached approximately $200 \mu \mathrm{m}$ there was a sudden change and, whereas the proportion of the cell distal to the lateral branches had been decreasing until cells reached this size, relative acropetal growth increased. Under long days a similar relationship was found for cells up to $200 \mu \mathrm{m}$ in length. Between cell lengths of 200-500 $\mu \mathrm{m}$ (few cells under short days even reached this length) there was no change in relative acropetal and basipetal expansion, with most of the values in the range of 4.5-6\%. After approximately $500 \mu \mathrm{m}$ length, the relative rate of acropetal expansion increased. When corresponding values for the light break and for 12-12 $\mathrm{h}$ were plotted (not shown), similar trends were obtained. Thus there was an increase in the range of cell lengths for which acropetal and basipetal cell expansion remained stable, with number of hours light per day. These ranges of cell length were about 200-300 $\mu \mathrm{m}$ and 200-400 $\mu \mathrm{m}$ for plants grown in the light break and in 12-12 $\mathrm{h}$ respectively. As with other aspects of vegetative growth, responses of plants under the light break were intermediate between those for 8 and $12 \mathrm{~h}$ light per day. This indicates that changing patterns of morphogenesis are due to photosynthetic and not photoperiodic responses of growth.

From the above results, three regions of cell growth can be distinguished in A. spirograpbidis in different parts of the main axis. The first region near the apex is characterized by relatively greater basipetal growth which continues down the plant until the cells have enlarged to approximately $200 \mu \mathrm{m}$ in length (Figs 17-18). This is followed by a region with equal acropetal and basipetal elongation, lasting over varying ranges of cell lengths. Finally, in the largest cells there is a region of increasing acropetal expansion. The sizes of these zones, or at least the range of cell lengths over which they occur, is partly controlled by light period.

In A. kylinii, Waaland \& Waaland (1975) demonstrated a single band at the base of axial cells in which elongation occurred. This is contrasted with $A$. spirographidis where two zones occur. Thus patterns of intracellular elongation can be used as a specific but not as a generic characteristic. Intracellular elongation in A. spirographidis is more similar to that found in Griffithsia pacifica and G. tenuis, 
where two zones of expansion were present. Changing patterns of acropetal and basipetal expansion were also found in G. pacifica (Waaland et al., 1972; Waaland \& Waaland, 1975) (using non-quantitative data) where the upper band of elongation was more active in younger cells, while in older cells expansion occurred in both bands. The patterns of elongation shown in this study for A. spirographidis are more complex than those shown previously and demonstrate the importance of light period in modifying aspects of intracellular development.

Acknowledgements. I would like to thank the Director and Staff of the Biologische Anstalt Helgoland (Meeresstation, Helgoland) where this work was carried out, and in particular Dr. K. Lüning for the use of culture facilities and considerable helpful advice. Dr. W. Farnham (Portsmouth Polytechnic) provided the material from which the Antithamnion spirographidis was isolated. I am also grateful to Dr. G. Russell (Liverpool University) for his helpful comments on the manuscript. Financial support from the Association of Commonwealth Universities is gratefully acknowledged.

\section{LITERATURE CITED}

Chapman, A. R. O. \& Burrows, E. M., 1970. Experimental investigations into the controlling effects of light condition on the development and growth of Desmarestia aculeata (L.) Lamour. Phycologia 9, 103-108.

Dixon, P. S., 1958. The morphology, ecology and taxonomy of certain Florideae. Br. phycol. Bull. 1, 32-33.

- 1963. Variation and speciation in marine Rhodophyta. In: Speciation in the sea. Ed. by J. P. Harding \& N. Tebble. Systematics Ass., London, 51-62.

- 1966. On the form of the thallus in the Florideophyceae. In: Trends in plant morphogenesis. Ed. by E. G. Cutter. Longmans, Green \& Co., London. 45-63.

- 1970. The Rhodophyta, some aspects of their biology. II. Oceanogr. mar. Biol. 8, 307-352.

- 1971. Cell enlargement in relation to the development of thallus form in Florideophyceae. Br. phycol. J. 6, 195-205.

- 1973. Biology of the Rhodophyta. Oliver \& Boyd, Edinburgh, $285 \mathrm{pp}$.

- \& Richardson, W. N., 1970. Growth and reproduction in red algae in relation to light and dark cycles. Ann. N. Y. Acad. Sci. 175, 764-777.

Duffield, E. C. S., Waaland, S. D. \& Cleland, R. 1972. Morphogenesis in the red alga, Griffitbsia pacifica: Regeneration from single cells. Planta 105, 185-195.

Garbary, D. J. 1975. The genus Ceramium: taxonomic, morphological and cultural investigations. M. Sc. thesis, Acadia University, Nova Scotia, 181 pp.

—, Grund, D. \& McLachlan, J. 1978. The taxonomic status of Ceramium rubrum (Huds.) C. Ag. (Ceramiales, Rhodophyceae) based on culture experiments. Phycologia 17, 85-94.

Konrad-Hawkins, E. 1964. Developmental studies on regenerates of Callithamnion roseum Harvey. Part II. Analysis of apical growth. Regulation of growth and form. Protoplasma 58, 60-74.

Murray, S. N. \& Dixon, P. S. 1973. The effect of light intensity and light period on the development of thallus form in the marine red alga Pleonosporium squarrulosum (Harvey) Abbott (Rhodophyta: Ceramiales). I. Apical cell division - main axes. J. exp. mar. Biol. Ecol. 13, 15-27.

- 1975. The effects of light intensity and light period on the development of thallus form in the marine red alga Pleonosporium squarrulosum (Harvey) Abbott (Rhodophyta: Ceramiales). II. Cell enlargement. J. exp. mar. Biol. Ecol. 19, 165-176. 
Provasoli, L. 1968. Media and the prospects for the cultivation of marine algae. In: Cultures and collection of algae. Ed. by A. Watanabe \& Hattori, Proc. U.S. - Japan Conf. of the Jap. Soc. Plant Physiol., Hakone, 1966, 63-75.

Stosch, H. A. von, 1964. Wirkung von Jod und Arsenit auf Meeresalgen in Kultur. Proc. int. Seaweed Symp. 4, 142-150.

Waaland, S. D. \& Cleland, R. 1972. Development in the red alga Griffithsia pacifica. Control by internal and external factors. Planta 105, 196-204.

- - \& Waaland, J. R. 1975. Analysis of cell elongation in red algae by fluorescent labelling. Planta 126, 127-138.

- \& Cleland, R. 1972. A new pattern of plant cell elongation: bipolar band growth. J. Cell Biol. 54, 184-190. 